продолжение школы: просто поучиться, а там видно будет. Исследование предполагается продолжить.

\title{
Урок-исследование «Распознавание основных классов неорганических веществ» как средство формирования учебно-познавательной компетенции учащихся
}

Федорова С.А., аспирант, Северо-Восточный федеральный университет, 2. Якутск E-mail: fedorova.sargylana@mail.ru

Научный руководитель: d.n.H., профессор Егорова К.E.

В настоящее время человек взаимодействует с огромным множеством материалов и веществ природного и антропогенного происхождения. Это взаимодействие отражает сложный комплекс отношений в системах «человек - вещество» и «вещество - материал - практическая деятельность». Результаты деятельности человека во многом определяются компетенциями.

На современном этапе развития школы требования к выпускнику сместились от предметных знаний и умений к его социальной компетентности, представляющей собой комплекс ключевых компетенций. Поэтому актуальным для современного образования становится поиск форм, методов и средств формирования у обучаемых системы универсальных знаний, умений и опыта самостоятельной деятельности, наличие которых необходимо человеку для успешного решения проблем в различных сферах жизни и профессиональной деятельности.

Введение ФГОС полностью переводит образование на компетентностный подход, точнее, на формирование у школьников ключевых компетенций, которые понимаются как целостная система универсальных знаний, умений, навыков, а также опыт самостоятельной деятельности и личной ответственности обучающихся $[1,2]$.

Теоретические основы компетентностного подхода исследовались крупными учеными И.А. Зимней, И.Я. Лернером, В.В. Краевским, В.В. Давыдовым, В.А. Болотовым, В.В. Сериковым, С.Е. Шишовым, А.В. Хуторским, М.М. Шалашовой, П.А. Оржековским, Л.М. Мещеряковой и др. [3,4,5,6,7]. Ими раскрыты сущность понятий и структурные компоненты ключевых компетенций.

В своем исследовании мы придерживались определения А.В. Хуторского:

- компетенция - совокупность взаимосвязанных качеств личности (знаний, умений, навыков, способов деятельности) необходимых для того, чтобы продуктивно действовать в социуме;

- компетентность - владение человека соответствующей компетенцией, включая его личностное отношение к ней и предмету деятельности [8].

Таким образом, компетентностный подход выступает как средство повышения качества образования, позволяющий учащимся освоить различные виды (роды) умения в процессе решения эффективно действовать в подобных ситуациях: личной, профессиональной и повседневной жизни. 
Одной из важнейших компетентностей учащихся является учебнопознавательная компетенция (УПК), которая представляет собой совокупность компетенций ученика в сфере самостоятельной познавательной деятельности, включающей элементы логической, методологической, общеучебной деятельности, соотнесенной с реальными познаваемыми объектами. Данная компетенция предполагает умение ученика самостоятельно ставить цели в процессе учебной деятельности, определять задачи для достижения цели, планировать, рефлексировать, анализировать свою деятельность: намечать содержание своей деятельности (что для этого я должен сделать?), средства, методы, примеры, решения задач (как я буду это делать?), что само по себе представляет большую сложность для школьников.

В Якутском хореографическом колледже в 8 классе был проведен урокисследование по теме: «Распознавание основных классов неорганических веществ». Целью урока является формирование и развитие учебно-познавательной компетенции учащихся.

Подготовка к уроку-исследованию проведена в 4 этапа: 1) распределение учащихся по группам-лабораториям; 2) групповая работа в лабораториях: поиск информации, работа с литературой, сбор материала, подготовка мультимедийной презентации; 3) ознакомление с техникой и методикой постановки опытов; 4) предварительная проверка подготовки лабораторий к уроку-исследованию.

Были сформированы 5 исследовательских лабораторий: 1. «Щелочи»; 2. «Кислоты»; 3. «Карбонаты»; 4. «Хлориды» и 5. «Сульфаты». В качестве домашнего задания каждая группа учащихся получила задание: поиск и сбор информации и подготовка презентации по своей теме исследования.

В лаборатории №1 в пробирку с гидроксидом натрия добавили фенолфталеин. Далее к раствору щелочи прилили раствор серной кислоты. Раствор приобрел малиновую окраску. Малиновая окраска исчезла, пробирка быстро разогрелась. Ребята сделали вывод, что щелочи можно распознавать по изменению окраски индикатора фенолфталеина и при добавлении кислоты к раствору щелочи происходит реакция обмена, который протекает с выделением теплоты и это реакция называется нейтрализацией.

Уравнение химической реакции: $\mathrm{NaOH}+\mathrm{H}_{2} \mathrm{SO}_{4} \rightarrow \mathrm{Na}_{2} \mathrm{SO}_{4}+\mathrm{H}_{2} \mathrm{O}$.

В лаборатории №2 был поставлен следующий интересный опыт: в пробирку с соляной кислотой добавили лакмус. Раствор приобрел розовую окраску. Таким образом, ребята выяснили, что кислоты можно распознавать по изменению окраски индикатора лакмуса.

Уравнение химической реакции: $\mathrm{HCl}+$ лакмус $\rightarrow$ розовая окраска.

В лаборатории №3 в пробирку с карбонатом натрия прилили соляную кислоту. Ребята наблюдали выделение пузырьков газа. Карбонаты распознаются по выделяющемуся газу при добавлении более сильной кислоты.

Уравнение химической реакции: $\mathrm{Na}_{2} \mathrm{CO}_{3}+2 \mathrm{HCl}=\mathrm{NaCl}+\mathrm{H}_{2} \mathrm{O}+\mathrm{CO}_{2} \uparrow$.

В лаборатории №4 налили в пробирку 2 мл хлорида калия и прилили 2 мл раствора нитрата серебра. Наблюдали выпадение белого осадка. Учащиеся сделали вывод о способе распознавания хлоридов. Хлориды распознаются по осадку, образующемуся при добавлении нитрата серебра.

Уравнение химической реакции: $\mathrm{KCl}+\mathrm{AgNO}_{3}=\mathrm{KNO}_{3}+\mathrm{AgCl} \downarrow$. 
В лаборатории №5 в пробирку с сульфатом меди прилили хлорид бария. Ребята отметили выпадение белого осадка сульфата бария, тем самым определили, что сульфаты распознаются по осадку, образующемуся при добавлении хлорида бария.

Уравнение химической реакции: $\mathrm{CuSO}_{4}+\mathrm{BaCl}_{2}=\mathrm{CuCl}_{2}+\mathrm{BaSO}_{4} \downarrow$.

В ходе урока-исследования учащиеся с большим желанием выполняли опыты, с удовольствием изучали свой объект исследования; проводили наблюдения за уникальными свойствами воды, устанавливали причинно-следственную связь между свойствами воды и планетарными явлениями. При этом, почувствовали себя настоящими исследователями и грамотно оформили результаты исследования и представили работу.

Педагогическим экспериментом подтверждена гипотеза о том, что выполнение исследовательских работ на уроке-исследования способствует эффективному формированию учебно-познавательной компетенции учащихся.

\title{
Список литературы:
}

1. ФГОС ООО. (Приказ МОиН РФ от 17.12.2010 №1897).

2. Концепция модернизации российского образования на период до 2010 года // Распоряжение правительства Российской Федерации от 29 декабря 2001 г. №1756-р.

3. Зимняя И.А. Ключевые компетенции - новая парадигма результата образования // Высшее образование сегодня. 2003.-№5.-с. 34-42.

4. Мещерякова Л.М., Шалашова М.М., Оржековский П.А. Формирование универсальных учебных действий: система дидактических заданий//Химия в школе.2013.-№1.-c.9-10.

5. Шалашова М.М., Абрамкина Л.М. Как оценивать личностные результаты учащихся//Химия в школе.-2013.-№3.-с.9.

6. Оржековский П.А, Титов Н.А. Чему учить и как учить?//Химия в школе.2013.-№2.-c.13-17.

7. Мещерякова Л.М. Обучение учащихся методом познания.//Химия в школе.2012.-№1.- c.54.

8. Хуторской А.В. Ключевые компетенции как компонент личностноориентированного образования//Народное образование. - 2003. - №2. - c.58-64.

Из опыта обучения старших дошкольников основам робототехники на базе набора Roborobo RoboKids

\author{
Хабарова Л.М., магистрант, \\ Северо-Восточный федеральный университет, \\ 2. Якутск \\ E-mail: habarova luba@mail.ru
}

Научный руководитель: к.ф.-м.н., доцент Максимов В.В.

Одними из главных задач, которые стоят сегодня перед педагогами дошкольных образовательных организаций в условиях введения Федерального государственного образовательного стандарта (ФГОС), являются социально-коммуникативное, познавательное, речевое, художественно-эстетическое и физическое развитие 